\title{
PEMETAAN TINDAK KRIMINALITAS DI KOTA PALOPO TAHUN 2015
}

\author{
${ }^{1}$ Alia Lestari, ${ }^{2}$ Muhammad Hajarul Aswad A \\ 1,2Institut Agama Islam Negeri (IAIN) Palopo \\ E-mail: ${ }^{1}$ entjenk@gmail.com , ${ }^{2}$ as wad82@yahoo.co.id
}

\begin{abstract}
:
The crime occurred in Palopo city each year is volatile enough. Although they tend to fall through leaving 176 cases in 2013, it does not mean that Palopo is fairly safe from the criminal acts. The societies of Palopo especially the polices, it is very important to know the areas included in the crime-prone areas. Therefore, this study tried to map the crimes occurred in Palopo city by applying Correspondence Analysis. The research objects were criminal data reported in the police of Palopo City since January to September 2015. From Chi-Square analysis, it was found that there was a relationship between the variables of Criminal Action Types and Occurrence Time. Similarly, the Criminal Action Types with Occurrence Places, and Criminal Action Types by the reasons occurring Criminal Acts also showed a relationship with criminal acts against the place and the reasons for the crimes. Furthermore, based on the correspondence analysis it was found that the largest crimes in the area of the police of Palopo are the theft of the motorcycles and the smallest crimes are persecutions. Most of time incidents occurred at 24.00-07.00. The crimes occurred in Wara district.
\end{abstract}

Keywords: Correspondence Analysis, Crime Mapping

\begin{abstract}
Abstrak:
Tindak kriminalitas yang terjadi di Kota Palopo setiap tahunnya cukup fluktuatif. Meskipun cenderung turun sampai menyisakan 176 kasus di tahun 2013, bukan berarti Palopo sudah terbilang aman dari tindakan kriminalitas. Masyarakat kota Palopo khususnya pihak kepolisian penting untuk mengetahui daerah mana saja yang termasuk dalam daerah rawan tindak kriminalitas. Untuk itu, penelitian ini mencoba untuk memetakan tindak kriminalitas yang terjadi di Kota Palopo dengan menerapkan Analisis Korespondensi. Objek dalam penelitian ini adalah data tindak kriminalitas yang terlaporkan di Polres Kota Palopo sejak bulan Januari 2015 sampai dengan September 2015. Dari analisis Chi-Square diperoleh bahwa ada hubungan antara variabel Jenis Tindakan Kriminalitas dengan variabel Waktu Kejadian. Begitu pula dengan Jenis Tindakan Kriminalitas dengan Tempat Kejadian, dan Jenis Tindakan Kriminalitas dengan Alasan Terjadinya Tindak Kriminalitas yang juga memperlihatkan adanya hubungan tindakan kriminalitas terhadap tempat dan alasan terjadinya tindak kriminalitas. Selanjutnya, berdasarkan analisis korespondensi diperoleh bahwa tindak kejahatan terbesar di wilayah hukum Polres Kota Palopo adalah pencurian kendaraan bermotor dan yg terkecil adalah penganiayaan. Waktu kejadian lebih banyak terjadi pada pukul 24.00-07.00. Tindakan kejahatan banyak terjadi di wilayah kecamatan Wara.
\end{abstract}

Kata Kunci : analisis korespondensi, kriminalitas, pemetaan 


\section{PENDAHULUAN}

Tindak kriminalitas yang terjadi di Kota Palopo setiap tahunnya cukup fluktuatif. Dari data yang ada terlihat bahwa jumlah tindakan kriminalitas terkecil terjadi pada tahun 2007 sedangkan yang terbesar terjadi pada tahun 2010. Meskipun cenderung turun sampai menyisakan 176 kasus di tahun 2013, bukan berarti Palopo sudah terbilang aman dari tindakan kriminalitas. Bahwa semua pihak tetap harus menjaga dan memelihara keamanan di wilayah masing-masing. Sampai tindakan kriminalitas memang benar-benar ditekan sampai pada angka yang wajar.

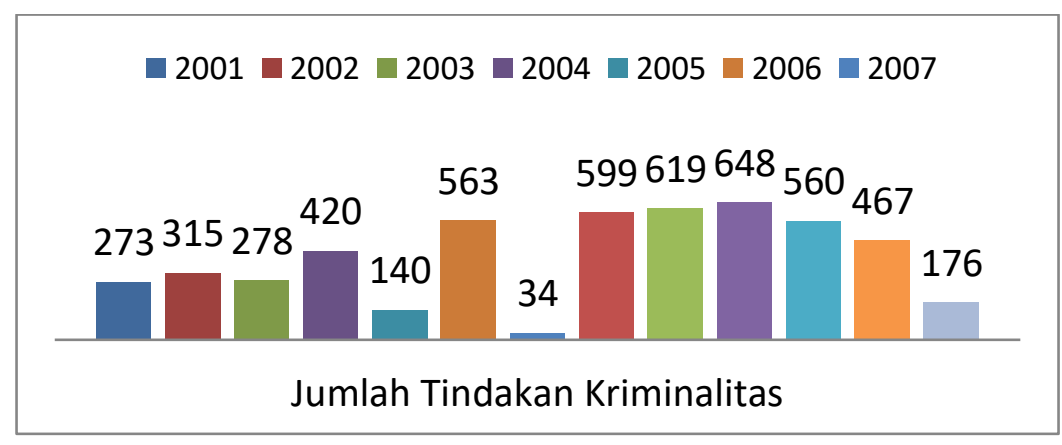

Sumber: Palopo dalam Angka 20141

Gambar 1. Jumlah Tindakan Kriminalitas di Kota Palopo Tahun 2001 sd 2013

Mencegah terjadinya tindakakan kriminalitas jelas menjadi tugas semua pihak, terlebih lagi aparat kepolisian. Untuk itu penting bagi kita semua untuk mengetahui lebih lanjut tentang waktu kejadian, tempat kejadian, alasan terjadinya tindakan kriminalitas, dan lainnya berdasarkan jenis tindakan kriminalitas yang terjadi. Mengetahui jenis tindakan kriminalitas A pada waktu dan lokasi tertentu jelas menjadi pencegahan awal yang sangat penting dan membantu. Berdasarkan hal tersebut, penelitian ini akan mencoba mendeskripsikan tindak kriminalitas yang terjadi di Kota Palopo dengan menerapkan salah satu metode dalam analisis Statistika, yaitu Analisis Korespondensi.

Analisis korespondensi telah cukup banyak diterapkan dalam membuat pemetaan terkait beberapa hal. Agus Rusgiyono melakukan analisis korespondensi untuk pemetaan persepsi masyarakat Semarang terhadap beberapa calon walikota yang ada pada tahun 2010. Lebih lanjut, Wara Pramesti melakukan analisisi korespondensi untuk mengetahui keterkaitan tindak pidana dengan usia, jenis kelamin, tingkat pendidikan, pekerjaan, dan alasan melakukan tindakan pidana dengan lokasi penelitian di Rumah

1BAPPEDA (Kota Palopo) and BPS (Kota Palopo), Palopo Dalam Angka 2014 (Palopo: BAPPEDA Kota Palopo, 2014).

PALITA: Journal of Social-Religi Research 
Tahanan Gresik pada tahun 2011. Sementara itu, Dewi Ayu Hidayati dkk melakukan analisis trend kejahatan dalam statistik Kepolisian Resort Kota Bandar Lampung tahun 2007 - 2011.

\section{KERANGKA TEORETIS}

\section{Tindak Kriminalitas}

Secara yuridis formal, kejahatan adalah bentuk tingkah laku yang bertentangan dengan moral kemanusiaan (immoril), merugikan masyarakat, a-sosial sifatnya dan melanggar hukum serta Undang-Undang pidana. Secara sosiologis, kejahatan adalah semua bentuk ucapan, perbuatan, dan tingkah laku yang secara ekonomis, politis dan sosial psikologis sangat merugikan masyarakat, melanggar norma-norma susila dan menyerang keselamatan warga masyarakat (baik yang telah tercantum maupun yang belum tercantum dalam undang-undang pidana). ${ }^{2}$

Beberapa jenis tindak kejahatan atau kriminalitas adalah sebagai berikut:

1. Jenis kriminalitas secara umum dapat diklasifikasikan menjadi: (1). Rampok dan gangsterisme, (2). Penipuan, (3). Pencurian dan pelanggaran lainnya.

2. Jenis kriminalias menurut cara dilakukan: (1). Menggunakan alat bantu, (2). Tanpa menggunakan alat bantu, (3). Residivis, (4). Penjahat berdarah dingin, yang melakukan kejahatan dengan pertimbangan dan persiapan yang matang, (5). Penjahat kesempatan, yang melakukan kejahatan dengan menggunakan kesempatan-kesempatan kebetulan, (6). Penjahat karena dorongan impuls-impuls yang timbul seketika, (7). Penjahat kebetulan, misalnya karena lupa diri, tidak sengaja, lalai, ceroboh, acuh tak acuh, sembrono, dan lain-lain.

3. Kriminalitas menurut objek hukum yang diserangnya: (1). Kejahatan ekonomi, (2). Kejahatan politik dan hankam, (3). Kejahatan kesusilaan, (4). Kejahatan terhadap jiwa orang dan harta benda.

4. Kriminalitas berdasarkan motif atau alasan-alasannya adalah motif ekonomis, politis, dan etis atau kesusilaan. ${ }^{3}$

${ }^{2}$ Kartini Kartono, Patologi Sosial (Jakarta: Rajawali, 1992).

${ }^{3}$ Ibid. 


\section{2 | Alia Lestari \& Muhammad Hajarul Aswad A}

Kepolisian Resort (Polres) Kota Palopo memiliki wilayah hukum yang mencakup wilayah administratif Kota Palopo. Wilayah yang dimaksud meliputi 9 kecamatan yaitu Wara Selatan, Sendana, Wara, Wara timur, Mungkajang, Wara Utara, Bara, Telluwanua, dan Wara Barat ${ }^{4}$. Selengkapnya dapat dilihat pada Gambar 2 berikut:

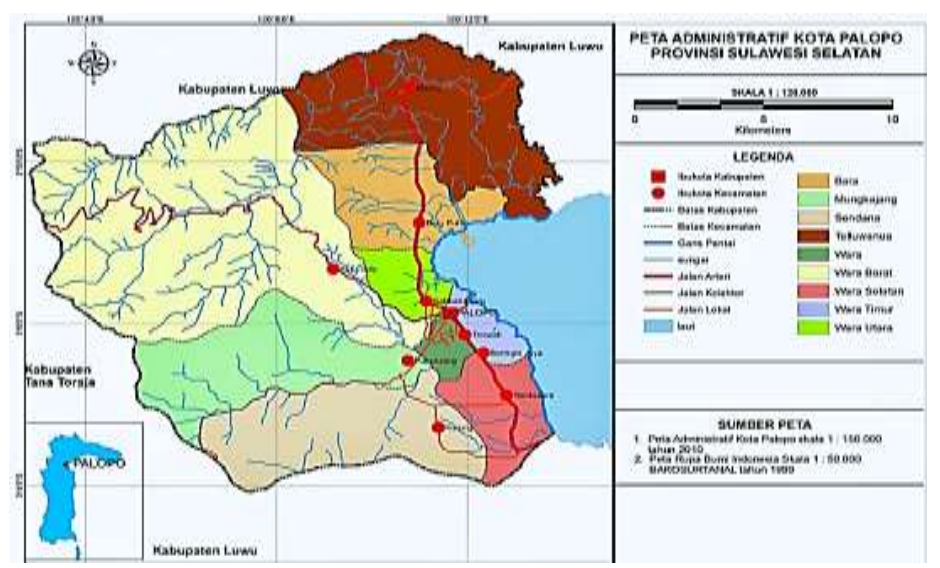

Gambar 2. Peta Wilayah Administratif Kota Palopo

Melihat letak Kota Palopo yang cukup strategis dan pembangunannya yang terus berkembang, maka sudah sewajarnya apabila semua pihak utamanya pihak Kepolisian Resort Kota Palopo mengetahui dengan pasti tindak kriminalitas apa saja yang sering terjadi, pada saat kapan, dimana, serta apa yang menjadi alasan sampai tindakan kriminalitas tersebut terjadi. Kesemuanya penting untuk menjaga dan menciptakan lingkungan Kota Palopo yang aman dari tindak kriminalitas.

\section{Analisis Korespondensi}

Analisis korespondensi merupakan salah satu bagian dari metode dalam analisis multivariate yang digunakan untuk menggambarkan hubungan diantara variabel yang bertipe diskrit (nominal / ordinal). Metode ini berbasis pada pengelompokkan objek berdasarkan kecenderungan tertentu.

Teknik yang digunakan pada analisis korespondensi pada dasarnya berbasis pada tabel kontingensi yang kemudian ditransformasikan ke dalam bentuk titik-titik gradien pada peta konfigurasi. Lewat peta konfigurasi tersebut, dapat diketahui bagaimana kecenderungan suatu kategori terhadap variabel tertentu. Interpretasinya adalah dengan melihat jarak antara titik yang mewakili satu kategori dengan titik variabel tertentu. Titik kategori

${ }^{4}$ M.H. Aswad, "Distribusi Jumlah Penduduk Kota Palopo (Suatu Analisis Tentang Pengaruh Distribusi Jumlah Sekolah Dan Jarak Tempuh Ibukota Kecamatan Dari Ibukota Palopo)," Al-Khwarizmi II, no. 1 Maret (2014): 15-26. 
yang jaraknya cukup dekat dengan salah satu titik variabel tertentu kemudian dikatakan bahwa titik kategori yang dimaksud cenderung mengarah ke titik variabel tersebut. ${ }^{5}$

Data yang berada dalam tabel kontingensi selanjutnya dapat digunakan untuk mengecek hubungan antara dua variabel yang dimaksud. Misalkan diketahui dua variabel $x$ dan $y$, maka asumsi independensi dapat dituliskan dalam bentuk probabilitas sebagai berikut:

$P\left(x_{i} y_{j}\right)=P\left(x_{i}\right) P\left(x_{j}\right)$, dengan $i=1,2, \ldots, a$; dan $j=1,2, \ldots, b$.

dengan $x_{i}$ dan $y_{j}$ berkorespondensi dengan baris ke-i dan kolom ke-j dari tabel kontingensi. Uji independensi $x$ terhadap $y$ dalam penelitian ini menggunakan uji statistik chi-square.

Nilai Singular, Inersia, dan Jarak Profil Baris - Kolom

Diketahui

$Z=D_{r^{-1 / 2}}\left(P-r c^{\prime}\right) D^{-1 / 2}$

yang element-elementnya adalah

$z_{i j}=\frac{p_{i j}-p_{i \square} p_{\square j}}{\sqrt{p_{i \sqsubset \square} p_{\square j}}}$

Suatu matriks $Z$ dengan ukuran $a \times$ memiliki rank $k=\min (a-1, b-1)$. Dengan dekomposisi nilai singular, didefinisikan matriks $Z$ sebagai berikut:

$Z=U \Lambda V^{\prime}$

dengan

$U=$ matriks dengan ukuran $a \times k$ yang merupakan vektoreigen dari matriks $Z Z^{\prime}$

$V=$ matrisk dengan ukuran $b \times k$ yang merupakan vektoreigen dari $Z^{\prime} Z$

$\Lambda=\operatorname{diag}\left(\lambda_{1}, \lambda_{2}, \ldots, \lambda_{\mathrm{k}}\right)$ dengan $\lambda_{1}{ }^{2}, \lambda_{2}{ }^{2}, \ldots, \lambda_{k}{ }^{2}$ adalah nilai eigen tak nol dari $Z^{\prime} Z$ dan $Z Z^{\prime}$

Perhatikan bahwa, nilai $\lambda_{1}, \lambda_{2}, \ldots, \lambda_{k}$ dari $\Lambda$ selanjutnya disebut dengan nilai singular dari $Z$. Untuk suatu nilai singular $\lambda_{i}$, maka didefinisikan beberapa hal berikut:

$$
\begin{aligned}
& \text { inersia }=\lambda i^{2}, \\
& \text { chi-square }=n \lambda_{i}{ }^{2},
\end{aligned}
$$

${ }^{5}$ Hardinus Usman and Nurdi Sobari, Aplikasi Teknik Multivariate (Jakarta: PT Raja Grafindo Persada, 2013). 


\section{METODE PENELITIAN}

Penelitian ini merupakan penelitian lapangan yang bersifat deskriptif kuantitatif. Dalam penelitian ini dilihat bagaimana hubungan antara satu variabel dengan variabel lainnya serta bagaimana kecenderungannya terhadap satu sama lain. Penelitian ini dilaksanakan di Kota Palopo dari bulan Agustus sampai 2015 dengan Oktober 2015. Data yang digunakan adalah data dokumentasi tindak kriminalitas yang terlaporkan di Polres Kota Palopo sejak bulan Januari 2015 sampai dengan September 2015. Jumlah data yang dimaksud sebanyak 99 kasus tindak kriminalitas lengkap beserta identitas waktu, lokasi, dan alasan melakukan tindak kriminalitas.

Data yang diperoleh kemudian diolah dengan prosedur sebagai berikut:

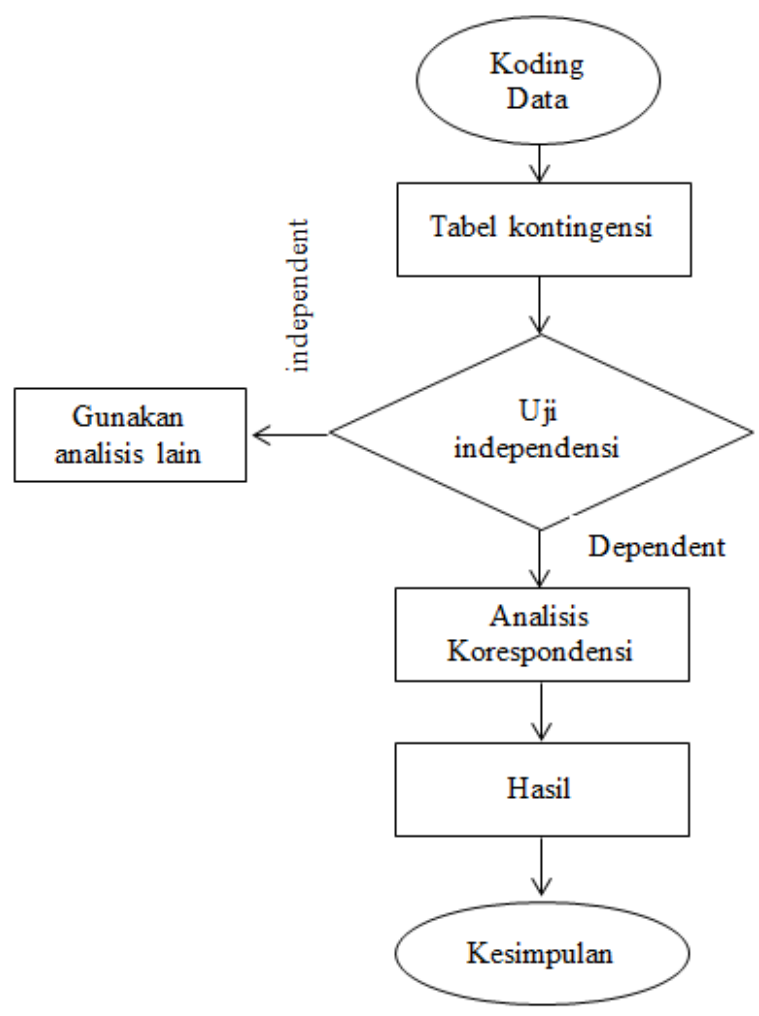

Gambar 3. Kerangka Pikir Penelitian 


\section{PEMETAAN TINDAK KRIMINALITAS DI KOTA PALOPO}

Deskripsi jenis tindakan kriminal, waktu, tempat, serta alasan terjadinya tindak kriminal di wilayah hukum Polres Kota Palopo berturutturut dijelaskan dalam gambar sebagai berikut:

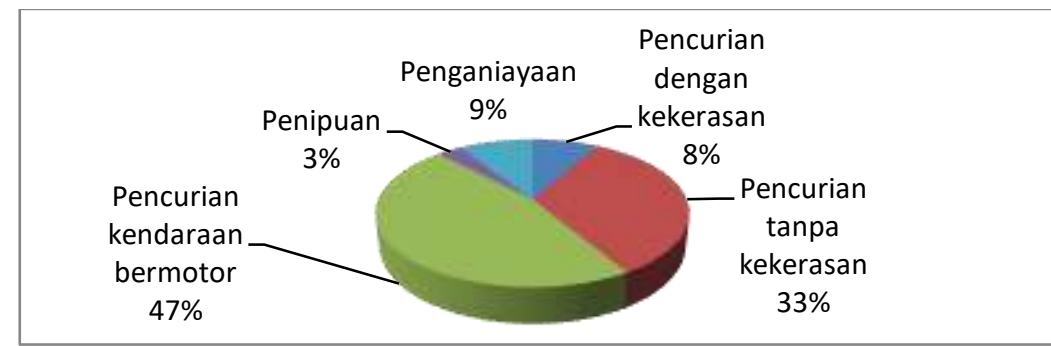

Gambar 4. Jenis Tindakan Kriminal di Wilayah Hukum Polres Kota Palopo

Bulan Januari 2015 - September 2015

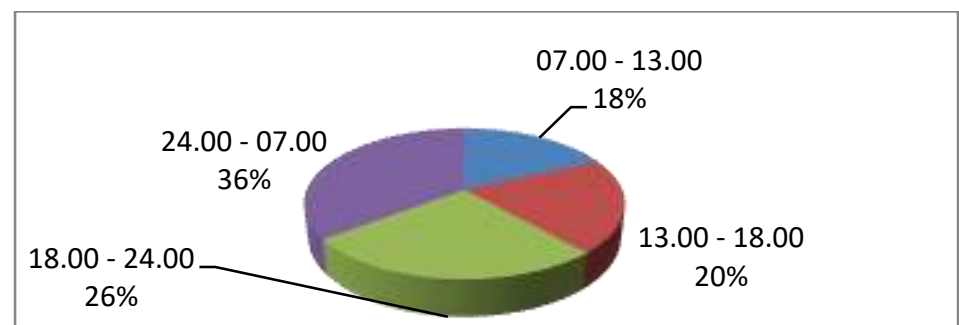

Gambar 5. Waktu Kejadian Tindakan Kriminal di Wilayah Hukum Polres Kota Palopo Bulan Januari 2015 - September 2015

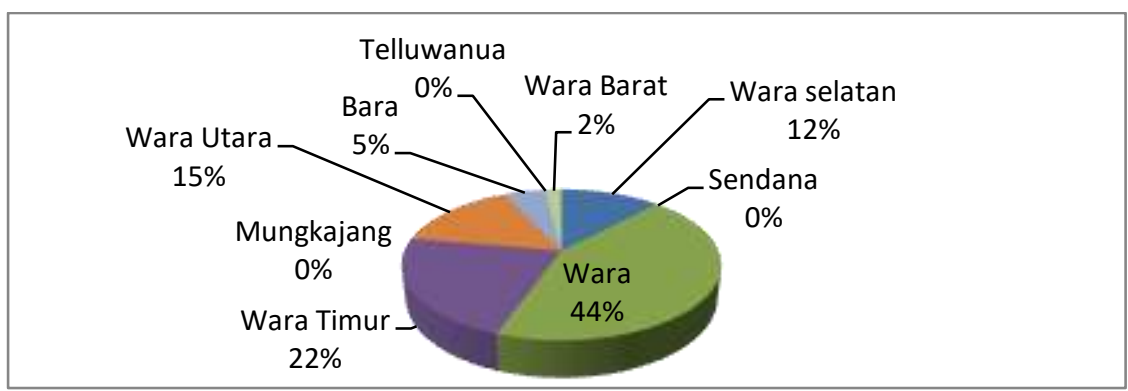

Gambar 6. Tempat Kejadian Tindakan Kriminal di Wilayah Hukum Polres Kota Palopo Bulan Januari 2015 - September 2015 


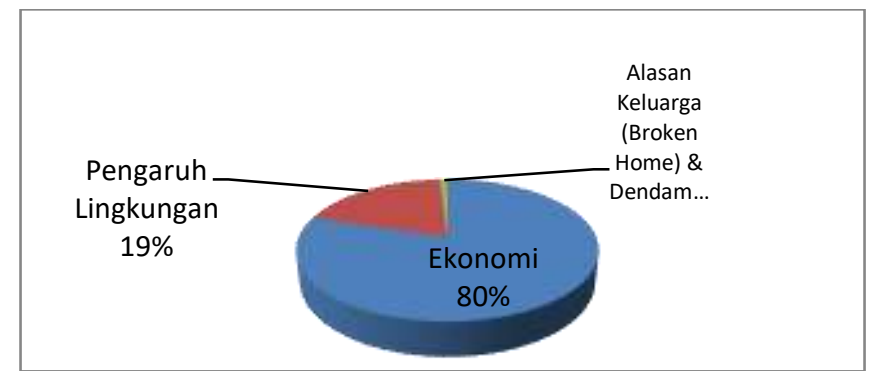

Gambar 7. Alasan Tindakan Kriminal di Wilayah Hukum Polres Kota Palopo Bulan Januari 2015 - September 2015

\section{TABEL KONTINGENSI}

Sebelum dilakukan uji independensi kemudian analisis korespondensi, terlebih dahulu data yang ada dibuat ke dalam bentuk tabel kontingensi. Karena dalam penelitian ini ingin dilihat kecenderungan jenis tindakan kriminal terhadap masing-masing variabel waktu, tempat, serta alasan terjadinya tindak kriminal, maka tabel kontingensi yang dibuat juga memperlihatkan hubungan tersebut. Berikut diberikan secara berturut-turut tabel kontingensi yang dimaksud.

Tabel 1. Tabel Kontingensi Tindakan Kejahatan terhadap Waktu Kejadian (Ket: Tindakan Kejahatan 1 = Pencurian dengan Kekerasan, $2=$ Pencurian Tanpa Kekerasan, 3 = Pencurian Kendaraan Bermotor, $4=$ Penipuan, $5=$ Penganiayaan; Waktu Kejadian $1=07.00-13.00,2=13.00-18.00,3=18.00$ -

\begin{tabular}{|c|c|c|c|c|c|}
\hline \multirow{2}{*}{$\begin{array}{l}\text { Tindakan } \\
\text { Kejahatan }\end{array}$} & \multicolumn{4}{|c|}{ Waktu Kejadian } & \\
\hline & 1 & 2 & 3 & 4 & Baris \\
\hline 1 & 1 & 0 & 2 & 5 & 8 \\
\hline 2 & 7 & 13 & 4 & 9 & 33 \\
\hline 3 & 5 & 28 & 5 & 8 & 46 \\
\hline 4 & 0 & 1 & 2 & 0 & 3 \\
\hline 5 & 5 & 0 & 3 & 1 & 9 \\
\hline Total Kolom & 18 & 42 & 16 & 23 & 99 \\
\hline
\end{tabular}


Tabel 2. Tabel Kontingensi Tindakan Kejahatan terhadap Tempat Kejadian (Ket: Tindakan Kejahatan 1 = Pencurian dengan Kekerasan, $2=$ Pencurian Tanpa Kekerasan, 3 = Pencurian Kendaraan Bermotor, $4=$ Penipuan, 5 = Penganiayaan; Tempat Kejadian $1=$ Wara Selatan, $2=$ Sendana, $3=$ Wara, $4=$ Wara Timur, $5=$ Mungkajang, $6=$ Wara Utara, $7=$ Bara, $8=$ Telluwanua, $9=$ Wara Barat).

\begin{tabular}{|c|c|c|c|c|c|c|c|c|c|c|}
\hline \multirow{2}{*}{$\begin{array}{c}\text { Tindakan } \\
\text { Kejahatan }\end{array}$} & 1 & 2 & 3 & 4 & 5 & 6 & 7 & 8 & 9 & $\begin{array}{c}\text { Total } \\
\text { Baris }\end{array}$ \\
\hline 1 & 1 & 0 & 1 & 0 & 0 & 4 & 2 & 0 & 0 & 8 \\
\hline 2 & 5 & 0 & 6 & 15 & 0 & 4 & 2 & 0 & 1 & 33 \\
\hline 3 & 3 & 0 & 29 & 9 & 0 & 3 & 1 & 0 & 1 & 46 \\
\hline 4 & 0 & 0 & 2 & 1 & 0 & 0 & 0 & 0 & 0 & 3 \\
\hline 5 & 0 & 0 & 5 & 4 & 0 & 0 & 0 & 0 & 0 & 9 \\
\hline Total Kolom & 9 & 0 & 43 & 29 & 0 & 11 & 5 & 0 & 2 & 99 \\
\hline
\end{tabular}

Tabel 3. Tabel Kontingensi Tindakan Kejahatan terhadap Alasan Melakukan Tindakan Kriminal

(Ket: Tindakan Kejahatan 1 = Pencurian dengan Kekerasan, $2=$ Pencurian Tanpa Kekerasan, 3 = Pencurian Kendaraan Bermotor, $4=$ Penipuan, 5 = Penganiayaan; Alasan Melakukan Tindakan Kriminal $1=$ Ekonomi, 2 = Pengaruh Lingkungan, 3 = Alasan Keluarga (Broken Home) \& Dendam).

\begin{tabular}{|c|c|c|c|c|}
\hline \multirow{2}{*}{$\begin{array}{c}\text { Tindakan } \\
\text { Kejahatan }\end{array}$} & \multicolumn{3}{|c|}{$\begin{array}{c}\text { Alasan Melakukan } \\
\text { Tindakan Kriminal }\end{array}$} & \multirow{2}{*}{$\begin{array}{c}\text { Total } \\
\text { Baris }\end{array}$} \\
\cline { 2 - 4 } & 1 & 2 & 3 & \\
\hline 1 & 7 & 1 & 0 & 8 \\
\hline 2 & 32 & 1 & 0 & 33 \\
\hline 3 & 32 & 14 & 0 & 46 \\
\hline 4 & 0 & 2 & 1 & 3 \\
\hline 5 & 9 & 0 & 0 & 9 \\
\hline Total Kolom & 80 & 18 & 1 & 99 \\
\hline
\end{tabular}

Terlebih dahulu dilakukan uji independensi terhadap keempat variabel yang ada. Dari analisis Chi-Square diperoleh bahwa ada hubungan antara variabel Jenis Tindakan Kriminalitas dengan variabel Waktu Kejadian. Begitu pula dengan Jenis Tindakan Kriminalitas dengan Tempat Kejadian, dan Jenis Tindakan Kriminalitas dengan Alasan Terjadinya Tindak Kriminalitas yang juga memperlihatkan adanya hubungan tindakan kriminalitas terhadap tempat dan alasan terjadinya tindak kriminalitas. 
38 | Alia Lestari \& Muhammad Hajarul Aswad A

Tabel 4. Analisis Chi-Square untuk Masing-Masing Variabel

\begin{tabular}{|c|c|c|c|c|}
\hline & & Value & $d f$ & $\begin{array}{c}\text { Asymp. Sig. } \\
\text { (2-sided) }\end{array}$ \\
\hline \multirow{4}{*}{\begin{tabular}{|l} 
Jenis Tindakan \\
Kriminalitas \\
dengan Waktu \\
Kejadian
\end{tabular}} & Pearson Chi-Square & $35,529 a$ & 12 &, 000 \\
\hline & Likelihood Ratio & 37,404 & 12 &, 000 \\
\hline & $\begin{array}{l}\text { Linear-by-Linear } \\
\text { Association }\end{array}$ & 4,875 & 1 & ,027 \\
\hline & $N$ of Valid Cases & 99 & & \\
\hline \multirow{4}{*}{\begin{tabular}{|l|} 
Jenis Tindakan \\
Kriminalitas \\
dengan Tempat \\
Kejadian
\end{tabular}} & Pearson Chi-Square & $43,143^{a}$ & 20 & ,002 \\
\hline & Likelihood Ratio & 42,036 & 20 &, 003 \\
\hline & $\begin{array}{l}\text { Linear-by-Linear } \\
\text { Association }\end{array}$ & 5,275 & 1 & ,022 \\
\hline & N of Valid Cases & 99 & & \\
\hline \multirow{4}{*}{$\begin{array}{l}\text { Jenis Tindakan } \\
\text { Kriminalitas } \\
\text { dengan Alasan } \\
\text { Terjadinya } \\
\text { Tindak } \\
\text { Kriminalitas } \\
\end{array}$} & Pearson Chi-Squar & $50,287^{a}$ & 8 &, 000 \\
\hline & Likelihood Ratio & 29,312 & 8 &, 000 \\
\hline & $\begin{array}{l}\text { Linear-by-Linear } \\
\text { Association }\end{array}$ & 2,516 & 1 & ,113 \\
\hline & N of Valid Cases & 99 & & \\
\hline
\end{tabular}

Selanjutnya akan dilihat bagaimana kecenderungan setiap kategori dalam masing-masing variabel terhadap jenis tindakan kriminalitas. Untuk keperluan tersebut, terlebih dahulu ditunjukkan matriks korespondensinya sebagai berikut:

Tabel 5. Matriks Korespondensi Tindakan Kejahatan terhadap Waktu Kejadian

\begin{tabular}{cccccc}
\hline Tindakan & \multicolumn{4}{c}{ Waktu Kejadian } & Total \\
\cline { 2 - 5 } Kejahatan & 1 & 2 & 3 & 4 & Baris \\
\hline 1 & 0,010 & 0,000 & 0,020 & 0,051 & 0,081 \\
\hline 2 & 0,071 & 0,131 & 0,040 & 0,091 & 0,333 \\
\hline 3 & 0,051 & 0,283 & 0,051 & 0,081 & 0,465 \\
\hline 4 & 0,000 & 0,010 & 0,020 & 0,000 & 0,030 \\
\hline 5 & 0,051 & 0,000 & 0,030 & 0,010 & 0,091 \\
\hline Total Kolom & 0,182 & 0,424 & 0,162 & 0,232 & 1,000 \\
\hline
\end{tabular}


Tabel 6. Matriks Korespondensi Tindakan Kejahatan terhadap Tempat Kejadian

\begin{tabular}{ccccccccccc}
\hline Tindakan & \multicolumn{1}{c}{ Tempat Kejadian } & Total \\
Kejahatan & 1 & 2 & 3 & 4 & 5 & 6 & 7 & 8 & 9 & Baris \\
\hline 1 & 0,010 & 0,000 & 0,010 & 0,000 & 0,000 & 0,040 & 0,020 & 0,000 & 0,000 & 0,081 \\
\hline 2 & 0,051 & 0,000 & 0,061 & 0,152 & 0,000 & 0,040 & 0,020 & 0,000 & 0,010 & 0,333 \\
\hline 3 & 0,030 & 0,000 & 0,293 & 0,091 & 0,000 & 0,030 & 0,010 & 0,000 & 0,010 & 0,465 \\
\hline 4 & 0,000 & 0,000 & 0,020 & 0,010 & 0,000 & 0,000 & 0,000 & 0,000 & 0,000 & 0,030 \\
\hline 5 & 0,000 & 0,000 & 0,051 & 0,040 & 0,000 & 0,000 & 0,000 & 0,000 & 0,000 & 0,091 \\
\hline Total Kolom & 0,091 & 0,000 & 0,434 & 0,293 & 0,000 & 0,111 & 0,051 & 0,000 & 0,020 & 1,000 \\
\hline
\end{tabular}

Tabel 7. Matriks Korespondensi Tindakan Kejahatan terhadap Alasan Melakukan Tindak Kriminal

\begin{tabular}{|c|c|c|c|c|}
\hline \multirow{2}{*}{$\begin{array}{l}\text { Tindakan } \\
\text { Kejahatan }\end{array}$} & \multicolumn{3}{|c|}{$\begin{array}{l}\text { Alasan Melakukan } \\
\text { Tindakan Kriminal }\end{array}$} & \multirow{2}{*}{$\begin{array}{l}\text { Total } \\
\text { Baris }\end{array}$} \\
\hline & 1 & 2 & 3 & \\
\hline 1 & 0,071 & 0,010 & 0,000 & 0,081 \\
\hline 2 & 0,323 & 0,010 & 0,000 & 0,333 \\
\hline 3 & 0,323 & 0,141 & 0,000 & 0,465 \\
\hline 4 & 0,000 & 0,020 & 0,010 & 0,030 \\
\hline 5 & 0,091 & 0,000 & 0,000 & 0,091 \\
\hline Total Kolom & 0,808 & 0,182 & 0,010 & 1,000 \\
\hline
\end{tabular}

Berdasarkan Tabel 7, diperoleh vektor kolom $r$ dan vektor baris $c$ sebagai berikut:

$r=(0,0810,3330,4650,0300,091)^{\prime}$ dan $c=(0,1820,4240,1620,232)$.

Kemudian diperoleh matriks diagonal baris $D_{r}$ dan matriks diagonal kolom $D_{c}$ sebagai berikut:

$$
\begin{aligned}
D_{r} & =\left(\begin{array}{lllll}
0,081 & 0,000 & 0,000 & 0,000 & 0,000 \\
0,000 & 0,333 & 0,000 & 0,000 & 0,000 \\
0,000 & 0,000 & 0,465 & 0,000 & 0,000 \\
0,000 & 0,000 & 0,000 & 0,030 & 0,000 \\
0,000 & 0,000 & 0,000 & 0,000 & 0,091
\end{array}\right), \\
D_{c} & =\left(\begin{array}{llll}
0,182 & 0,000 & 0,000 & 0,000 \\
0,000 & 0,424 & 0,000 & 0,000 \\
0,000 & 0,000 & 0,162 & 0,000 \\
0,000 & 0,000 & 0,000 & 0,232
\end{array}\right)
\end{aligned}
$$


Dari matriks korespondensi, $D r$ dan $D c$, diperoleh profil baris $R$ dan profil kolom $C$ sebagai berikut:

$$
R=\left(\begin{array}{llll}
0,125 & 0,000 & 0,250 & 0,625 \\
0,212 & 0,394 & 0,121 & 0,273 \\
0,109 & 0,609 & 0,109 & 0,174 \\
0,000 & 0,333 & 0,667 & 0,000 \\
0,556 & 0,000 & 0,333 & 0,111
\end{array}\right) \text {, dan } C=\left(\begin{array}{llll}
0,056 & 0,000 & 0,125 & 0,217 \\
0,389 & 0,310 & 0,250 & 0,391 \\
0,278 & 0,667 & 0,313 & 0,348 \\
0,000 & 0,024 & 0,125 & 0,000 \\
0,278 & 0,000 & 0,188 & 0,043
\end{array}\right)
$$

Berdasarkan Persamaan (3) diperoleh matriks Z sebagai berikut:

$$
\begin{aligned}
Z & =\left(\begin{array}{cccc}
-0,038 & -0,185 & 0,062 & 0,232 \\
0,041 & -0,027 & -0,058 & 0,048 \\
-0,117 & 0,193 & -0,090 & -0,083 \\
-0,074 & -0,024 & 0,219 & -0,084 \\
0,264 & -0,196 & 0,129 & -0,076
\end{array}\right) \\
Z Z^{\prime} & =\left(\begin{array}{ccccc}
0,093 & 0,011 & -0,056 & 0,002 & 0,017 \\
0,011 & 0,008 & -0,009 & -0,019 & 0,005 \\
-0,056 & -0,009 & 0,066 & -0,009 & -0,074 \\
0,002 & -0,019 & -0,009 & 0,061 & 0,020 \\
0,017 & 0,005 & -0,074 & 0,020 & 0,131
\end{array}\right)
\end{aligned}
$$

Dengan menyelesaikan $\left|Z Z^{\prime}-\lambda I\right|=0$ dengan I suatu matriks identitas, maka diperoleh nilai eigen tak nol $\lambda_{1}=0,203, \lambda_{2}=0,095$, dan $\lambda_{3}=0,062$. Karena nilai eigen tak nol dari ZZ' dinotasikan dengan $\lambda_{1}{ }^{2}, \lambda_{2}{ }^{2}, \ldots, \lambda_{k}{ }^{2}$ maka $\lambda_{1}{ }^{2}$ $=0,203, \lambda_{2}{ }^{2}=0,095$, dan $\lambda_{3}{ }^{2}=0,062$. Sehingga, nilai singular dari matriks Z adalah $\lambda_{1}=0,450, \lambda_{2}=0,307$, dan $\lambda_{3}=0,248$. Selanjutnya, berdasarkan Persamaan (9), (10), dan (11), maka diperoleh: Nilai inersia : $\lambda_{1}{ }^{2}=0,203, \lambda_{2}{ }^{2}$ $=0,095$, dan $\lambda_{3}{ }^{2}=0,062$, Nilai total chi-square : 35,529, dan Proporsi inersia : 0,$565 ; 0,263$; dan 0,172 .

\section{ANALISIS KORESPONDENSI}

Untuk analisis korespondensi antara Tindakan Kejahatan terhadap Tempat Kejadian dan Alasan Melakukan Tindakan Kejahatan, selanjutnyan diselesaikan dengan menggunakan SPSS. Interpretasi output dari ketiga kemungkinan tersebut dijelaskan melalui chart berikut ini. 
Analisis Korespondensi Jenis Tindak Kriminal dengan Waktu Kejadian

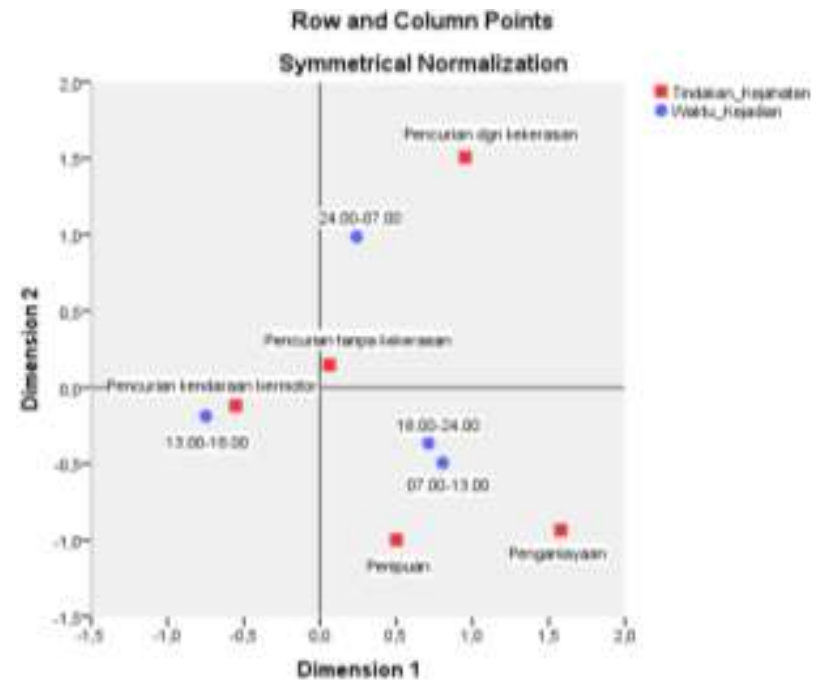

Gambar 8. Peta Persepsi Kecenderungan Waktu Kejadian terhadap Jenis Tindakan Kriminal

Berdasarkan Gambar 8 terlihat bahwa pencurian kendaraan bermotor cenderung terjadi pada pukul 13.00 - 18.00. Pencurian baik dengan kekerasan maupun tanpa kekerasan cenderung untuk terjadi pada lewat tengah malam yakni pukul 24.00 - 07.00. Sementara penipuan dan penganiayan cenderung terjadi pada pukul $18.00-24.00$ dan $07.00-13.00$.

Analisis Korespondensi Jenis Tindak Kriminal dengan Tempat Kejadian

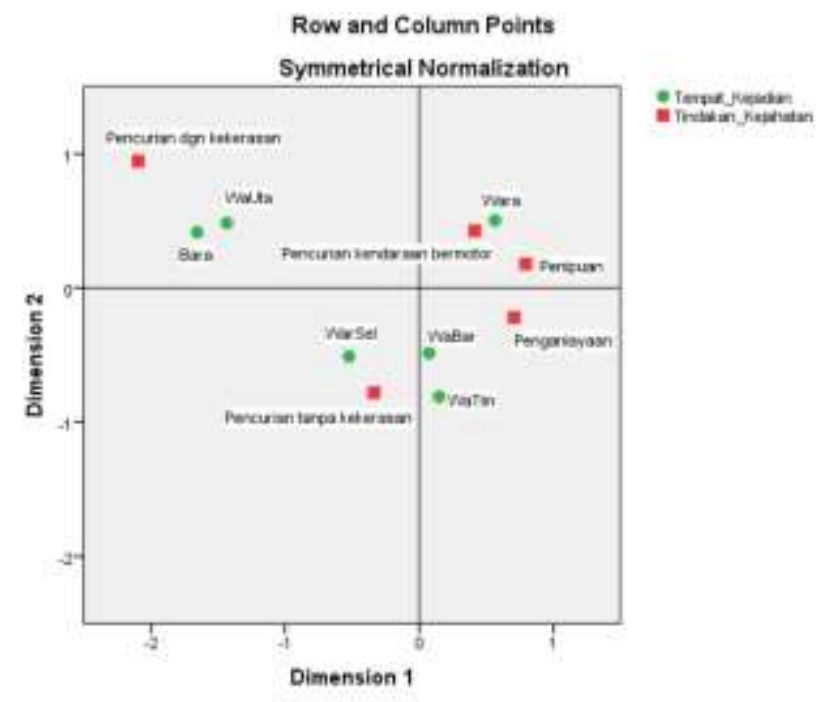

Gambar 9. Peta Persepsi Kecenderungan Tempat Kejadian terhadap Jenis Tindakan Kriminal 


\section{2 | Alia Lestari \& Muhammad Hajarul Aswad A}

Berdasarkan Gambar 9 terlihat bahwa pencurian dengan kekerasan cenderung terjadi di Kecamatan Bara dan Wara Utara, sementara pencurian tanpa kekerasan cenderung terjadi di Wara Selatan, Wara Barat dan Wara Timur. Pencurian kendaraan bermotor, penipuan, dan penganiayaan cenderung terjadi di Kecamatan Wara.

Analisis Korespondensi Jenis Tindak Kriminal dengan Alasan Terjadinya Tindak Kriminal

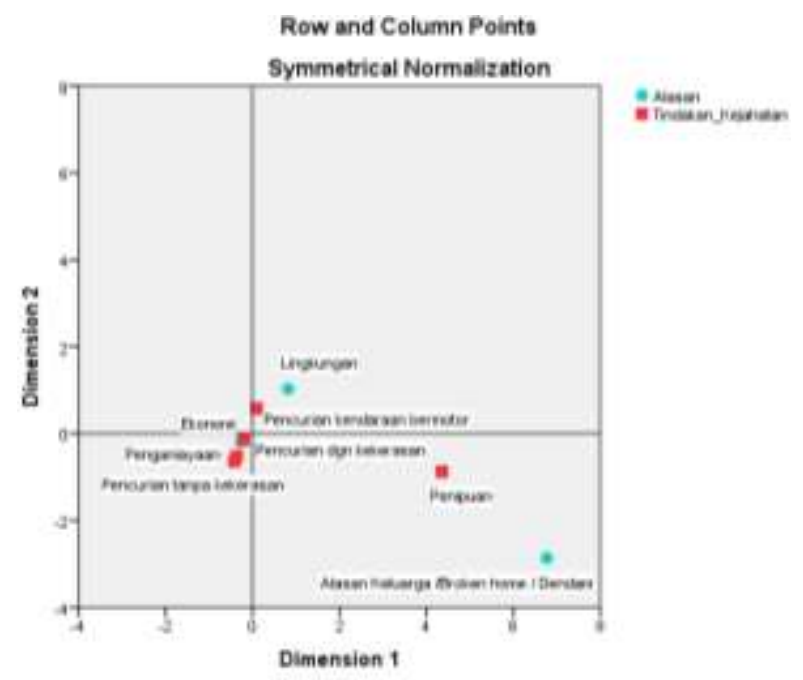

Gambar 10. Peta Persepsi Kecenderungan Tempat Kejadian terhadap Alasan Terjadinya Tindak Kriminal

Berdasarkan Gambar 10 terlihat bahwa sebagian besar tindak kriminalitas disebabkan oleh alasan ekonomi dan lingkungan. Hanya tindak penipuan yang disebabkan oleh alasan keluarga.

\section{PENUTUP}

Berdasarkan hasil penelitian dan pembahasan yang telah dilakukan dapat disimpulkan sebagai berikut:

1. Tindak kejahatan terbesar di wilayah hukum Polres Kota Palopo adalah pencurian kendaraan bermotor dan yg terkecil adalah penganiayaan. Waktu kejadian lebih banyak terjadi pada pukul 24.00-07.00. Tindakan kejahatan banyak terjadi di wilayah kecamatan Wara.

2. Kecenderungan hubungan tindak kriminalitas terhadap waktu kejadian, tempat kejadian, serta alasan terjadinya tindak kriminalitas adalah sebagai berikut:

a. Pencurian kendaraan bermotor cenderung terjadi pada pukul $13.00-$ 18.00. Pencurian baik dengan kekerasan maupun tanpa kekerasan cenderung untuk terjadi pada lewat tengah malam yakni pukul 24.00 
- 07.00. sementara penipuan dan penganiayan cenderung terjadi pada pukul 18.00 - 24.00 dan 07.00 - 13.00 .

b. Pencurian dengan kekerasan cenderung terjadi di Kecamatan Bara dan Wara Utara, sementara pencurian tanpa kekerasan cenderung terjadi di Wara Selatan, Wara Barat dan Wara Timur. Pencurian kendaraan bermotor, penipuan, dan penganiayaan cenderung terjadi di Kecamatan Wara.

c. Sebagian besar tindak kriminalitas disebabkan oleh alasan ekonomi dan lingkungan. Hanya tindak penipuan yang disebabkan oleh alasan keluarga.

Berdasarkan hasil penelitian yang telah diperoleh maka diperlukan kewaspadaan bagi kita semua untuk menghindari daerah dan waktu-waktu rawan kasus tindak kriminalitas. Bagi aparat keamanan khusunya aparat Polres Kota Palopo dapat memikirkan langkah prefentif untuk mencegah terjadinya tindak kriminalitas terkait tempat dan waktu rawan tindakan kejahatan, misalnya dengan mengadakan patroli pada tempat dan waktu yang dimaksud. Sementara untuk pengembangan penelitian ini, diharapkan variabel terkait jenis tindakan kriminalitas bisa diperluas dan dikaji lebih dalam lagi. Selain itu, menjadi sesuatu yang menarik untuk meramalkan kecenderungan terjadinya tindak kriminalitas tertentu dengan menggunakan data yang telah ada sebelumnya.

\section{DAFTAR PUSTAKA}

Admin. "Kejamnya Keadilan Sandal Jepit." Kompas, 2015. http://nasional.kompas.com/read/2012/01/06/09445281/Kejamnya.K eadilan.Sandal.Jepit.

Alam, A.S, and Amir Ilyas. Pengantar Kriminologi. Makassar: Pustaka, 2010.

Aswad, M.H. "Analisis Peramalan Jumlah Penduduk Kota Palopo Tahun 2013 - 2017." Al-Khwarizmi I, no. 1 Maret (2013): 49-58.

_-_. "Distribusi Jumlah Penduduk Kota Palopo (Suatu Analisis Tentang Pengaruh Distribusi Jumlah Sekolah Dan Jarak Tempuh Ibukota Kecamatan Dari Ibukota Palopo)." Al-Khwarizmi II, no. 1 Maret (2014): $15-26$.

BAPPEDA (Kota Palopo), and BPS (Kota Palopo). Palopo Dalam Angka 2014. Palopo: BAPPEDA Kota Palopo, 2014.

Greenacre, Michael. Correspondence Analysis in Practice 2nd Edition. 2nd ed. New York: Chapman \& Hall, 2014.

Hair Jr, Joseph F. Multivariate Data Analysis. 7th ed. New Jersey: Prentice-Hall, 2007.

Hidayati, Dewi Ayu, Ikram, and Teuku Fahmi. "Analisis Trend Kejahatan 


\section{4 | Alia Lestari \& Muhammad Hajarul Aswad A}

Dalam Statistik Kepolisian (Studi Di Wilayah Hukum Kepolisian Resort Kota Bandar Lampung Tahun 2007-2011)." Seminar Hasil-Hasil Penelitian Dan Pengabdian Kepada Masyarakat- Dies Natalis FISIP Unila Tahun 2012 ANALISIS, no. 2012 (2012): 84-93.

Kartono, Kartini. Patologi Sosial. Jakarta: Rajawali, 1992.

Lestari, Alia. "Segmentasi Pasar Menggunakan Correspondence Alaysis." AlKhwarizmi II, no. 2 Oktober (2014): 155-66.

Pramesti, Wara. "Analisis Korespondensi Untuk Mengetahui Keterkaitan Tindak Pidana Dengan Usia, Jenis Kelamin, Tingkat Pendidikan, Pekerjaan, Dan Alasan Melakukan Tindakan Pidana." Jurnal J-Statistika 4, no. 2 (2011): 41-54.

Rencher, Alvin C. Methods of Multivariate Analysis. Canada: Wiley Insterscience, 2002.

Rusgiyono, Agus. "Analisis Korespondensi Untuk Pemetaan Persepsi." Jurnal Media Statistika 3, no. 2 (2010): 117-23.

Usman, Hardinus, and Nurdi Sobari. Aplikasi Teknik Multivariate. Jakarta: PT Raja Grafindo Persada, 2013. 
Sumber pustaka ${ }^{6}$

Sumber tambahan ${ }^{7}$

${ }^{6}$ A.S Alam and Amir llyas, Pengantar Kriminologi (Makassar: Pustaka, 2010); M.H. Aswad, "Analisis Peramalan Jumlah Penduduk Kota Palopo Tahun 2013 - 2017," Al-Khwarizmi I, no. 1 Maret (2013): 49-58; Aswad, “Distribusi Jumlah Penduduk Kota Palopo (Suatu Analisis Tentang Pengaruh Distribusi Jumlah Sekolah Dan Jarak Tempuh Ibukota Kecamatan Dari Ibukota Palopo)"; BAPPEDA (Kota Palopo) and BPS (Kota Palopo), Palopo Dalam Angka 2014; Michael Greenacre, Correspondence Analysis in Practice 2nd Edition, 2nd ed. (New York: Chapman \& Hall, 2014); Joseph F Hair Jr, Multivariate Data Analysis, 7th ed. (New Jersey: Prentice-Hall, 2007); Dewi Ayu Hidayati, Ikram, and Teuku Fahmi, "Analisis Trend Kejahatan Dalam Statistik Kepolisian (Studi Di Wilayah Hukum Kepolisian Resort Kota Bandar Lampung Tahun 2007-2011)," Seminar Hasil-Hasil Penelitian Dan Pengabdian Kepada Masyarakat- Dies Natalis FISIP Unila Tahun 2012 ANALISIS, no. 2012 (2012): 84-93; Admin, "Kejamnya Keadilan Sandal Jepit," Kompas, 2015, http://nasional.kompas.com/read/2012/01/06/09445281/Kejamnya.Keadilan.Sandal.Jepit; Kartono, Patologi Sosial; Alia Lestari, "Segmentasi Pasar Menggunakan Correspondence Alaysis," Al-Khwarizmi II, no. 2 Oktober (2014): 155-66; Wara Pramesti, "Analisis Korespondensi Untuk Mengetahui Keterkaitan Tindak Pidana Dengan Usia, Jenis Kelamin, Tingkat Pendidikan, Pekerjaan, Dan Alasan Melakukan Tindakan Pidana," Jurnal J-Statistika 4, no. 2 (2011): 41-54; Alvin C Rencher, Methods of Multivariate Analysis (Canada: Wiley Insterscience, 2002); Agus Rusgiyono, “Analisis Korespondensi Untuk Pemetaan Persepsi," Jurnal Media Statistika 3, no. 2 (2010): 117-23; Usman and Sobari, Aplikasi Teknik Multivariate.

${ }^{7}$ Rencher, Methods of Multivariate Analysis; Rusgiyono, "Analisis Korespondensi Untuk Pemetaan Persepsi"; Usman and Sobari, Aplikasi Teknik Multivariate. 